\title{
Molecular Characterization and Genetic Diversity of Yellow Passion Fruit Based on RAPD Markers
}

\author{
Angélica Vieira Sousa Campos ${ }^{1}$, José Ricardo Peixoto ${ }^{1}$, Fábio Gelape Faleiro ${ }^{2}$, \\ Michelle Souza Vilela ${ }^{1} \&$ Márcio de Carvalho Pires ${ }^{1}$ \\ ${ }^{1}$ Faculty of Agronomy and Veterinary Medicine, University of Brasilia, Brasilia, Brazil \\ ${ }^{2}$ Brazilian Agricultural Research Corporation, Embrapa Cerrados, Planaltina, Brazil \\ Correspondence: Angélica Vieira Sousa Campos, Faculty of Agronomy and Veterinary Medicine, University of \\ Brasilia, Brasilia, DF, 70910-900, Brazil. Tel: 55-61-9218-1207. E-mail: angelicavsc1@gmail.com
}

Received: October 23, 2018

Accepted: November 30, 2018

Online Published: February 15, 2019

doi:10.5539/jas.v11n3p575

URL: https://doi.org/10.5539/jas.v11n3p575

\begin{abstract}
Molecular genetic variability studies are essential to complement the agronomic characterization of yellow passion fruit genotypes (Passiflora edulis Sims). Therefore, this study aimed at evaluating the genetic diversity of 24 genotypes of yellow passion fruit obtained from a research program developed by the University of Brasilia and Embrapa Cerrados, using RAPD molecular markers. RAPD markers were obtained from eight decamer primers and converted into a matrix of binary data, from which genetic dissimilarities among genotypes were estimated, and clustering analysis was performed. A total of 54 RAPD markers were obtained, with 6.8 bands per primer on average. From this total, $46(85.2 \%)$ RAPD markers were polymorphic. The OPD10 primer presented the highest number of polymorphic bands. The high percentage of polymorphic markers evidenced the existence of genetic variability among genotypes. Nei's genetic distance between genotypes ranged from 0.043 to 0.451 . Clustering resulted in the formation of at least five groups of similarity.
\end{abstract}

Keywords: genetic breeding, genetic variability, Passiflora edulis

\section{Introduction}

Passiflora is the numerically and economically most important genus of the Passifloraceae family. Its species are popularly known as passion fruit and have tropical and subtropical distribution. Among the 150 accepted species in Brazil (Bernacci et al., 2015), 70 produce edible fruits and, consequently, exhibit great economic importance for the Brazilian fruticulture (Cunha \& Barbosa, 2002). Yellow passion fruit (Passiflora edulis Sims) is the species with the highest economic importance in the country due to its fruit quality, fruit yield, and industrial yield (Meletti \& Brückner, 2001).

The Brazilian mean yield of yellow passion fruit is approximately $14.1 \mathrm{t} \mathrm{ha}^{-1}$ year $^{-1}$ (Anuário Brasileiro da Fruticultura $[\mathrm{ABF}], 2018$ ). Increased yields have been recently reported in the Brazilian savanna region. However, the national average is still considered as low based on the productive potential of the genetically improved cultivars grown under appropriate crop management practices (Neves, Jesus, Ledo, \& Oliveira, 2013). Despite the low yields recorded, Brazil is the world's largest producer and consumer of passion fruit (ABF, 2018).

Breeding practices represent one of the most important strategies to increase yield, fruit quality, and disease resistance in passion fruit (Santos et al., 2011). As Passiflora is highly diverse, the characterization and utilization of this biological diversity may provide useful information for breeding programs with different results (Cerqueira-Silva, Jesus, Santos, Corrêa, \& Souza, 2014). However, proper evaluation and quantification are required for efficient use of the genetic variability (Santos et al., 2011).

Studies into the genetic diversity of accessions generate important and useful information for germplasm collection, maintenance, and characterization (Faleiro et al., 2004). In this context, the use of DNA molecular markers and classical breeding procedures has been suggested as essential strategies to accelerate the production of new varieties that are adapted to different Brazilian regions (M. G. Pereira, T. N. S. Pereira, \& Viana, 2005).

Among the different types of DNA molecular markers, RAPD (Random Amplified Polymorphic DNA), the most prevalent markers used in Passiflora diversity studies (Cerqueira-Silva et al., 2014), have been successfully used 
to demonstrate the existence of high genetic variability among Passiflora accessions (Bellon et al., 2005; Bellon, Faleiro, Junqueira, \& Junqueira, 2007; F. G. Faleiro, A. S. G. Faleiro, Cordeiro, \& Karia, 2003). As a result, RAPD markers have extensively contributed to the selection of parents and development of crossing plans in genetic breeding programs, as well as to the selection of improved plant materials (Bellon, Faleiro, Junqueira, \& Fuhrmann, 2014; Fonseca, Faleiro, Junqueira, Barth, \& Feldberg, 2017). Therefore, the objective of this study was to evaluate the genetic diversity of 24 genotypes of yellow passion fruit using RAPD molecular markers.

\section{Method}

The experiment was performed in the Laboratory of Genetic and Molecular Biology at Embrapa Cerrados, Planaltina, DF, Brazil. The evaluated genotypes were obtained from a research program developed by the University of Brasilia (UnB) and Embrapa (Empresa Brasileira de Pesquisa Agropecuária-Brazilian Agricultural Research Corporation), which used yield and disease resistance as selection criteria. MSCA is derived from cultivar Marília Seleção Cerrado whereas MSCA PL1 was obtained by recurrent selection based on half-sib family. EC-L-7 is derived from cultivar Marília, and EC-3-0 is a hybrid (RC1) obtained from controlled pollination between Marília x Roxo Australiano cultivars backcrossed with Marília (F1 × Marília). AR02 was originated by individual selection from anthracnose resistant plants of Roxo Australiano family. Genotypes MAR20\#12 PL1, MAR20\#15, MAR20\#19, MAR20\#24 PL1, MAR20\#34 F2, MAR20\#39, MAR20\#41, MAR20\#44, MAR20\#46, MAR20\#49, MAR20\#2005 PL1, MAR20\#2005 PL2, AP01, Gigante Amarelo PL1, Rosa Intenso PL1, Rosa Intenso 3, Rosa Claro PL1, Rosa Claro PL2, and Rubi Gigante PL2 were obtained by recurrent selection based on half-sib family.

Leaf samples were collected from each genotype and immediately used to extract the genomic DNA using a modified CTAB method (Faleiro et al., 2003). DNA samples were amplified by the RAPD technique. The DNA amplification reaction volume was $13 \mu \mathrm{L}$. Each reaction contained $10 \mathrm{mM}$ Tris- $\mathrm{HCl}(\mathrm{pH} 8.3), 50 \mathrm{mM} \mathrm{KCl}, 3$ $\mathrm{mM} \mathrm{MgCl} 2,100 \mu \mathrm{M}$ each of the four dNTPs (dATP, dTTP, dGTP, and dCTP), $0.4 \mu \mathrm{m}$ primer (Operon Technologies Inc., Alameda, CA, USA.), $1 \mathrm{U}$ Taq polymerase, and $15 \mathrm{ng}$ of one DNA. Eight RAPD decamer oligonucleotide primers were utilized to obtain RAPD markers: OPD (04, 07, 08, and 10), OPE (16), OPF (01), OPG (05), OPH (12). The amplifications were performed in a thermocycler programmed to 40 cycles of denaturation $\left(94{ }^{\circ} \mathrm{C}, 15 \mathrm{~s}\right)$, primer annealing $\left(35^{\circ} \mathrm{C}, 30 \mathrm{~s}\right)$, and primer extension $\left(72{ }^{\circ} \mathrm{C}, 90 \mathrm{~s}\right)$. At the end of the 40 cycles, an extension step of 6 min at $72{ }^{\circ} \mathrm{C}$ was added, followed by temperature reduction to $4{ }^{\circ} \mathrm{C}$. After amplification, $3 \mu \mathrm{l}$ of a mixture of bromophenol blue $(0.25 \%)$ and glycerol $(60 \%)$ were added to each sample. The amplified fragments were separated in a 1.2\% agarose gel in TBE (Tris-Borato $90 \mathrm{mM}$, EDTA $1 \mathrm{mM}$ ) buffer with ethidium bromide. The electrophoresis process occurred at $90 \mathrm{~V}$ and lasted for about four hours. Immediately after electrophoresis, the gel was visualized and photographed under ultraviolet light.

The reproducible RAPD markers were converted into a binary data matrix. The genetic distance among genotypes was estimated based on the complement of Nei and Li's similarity coefficient (1979), using Genes software (Cruz, 2013). The matrix of genetic distance was used for genotype clustering based on the unweighted pair group method with arithmetic mean (UPGMA). In addition, a graphical dispersion was generated based on the Multidimensional Scale (MDS) using the principal coordinates method. Analyses were performed using the statistical analysis system (SAS, 2004) and Statistica (Statsoft, 2000) software.

\section{Results and Discussion}

The eight primers generated a total of 54 RAPD markers. From this total, 46 (85.2\%) RAPD markers were polymorphic. These results exhibit a polymorphism higher than the reported by Kososki (2014), who worked with $P$. edulis genotypes considered as promising sources of disease resistance (51.5\%). The OPD10 primer presented the highest number of polymorphic bands whereas OPE16 exhibited the highest number of monomorphic bands (Table 1). 
Table 1. Primers used to obtain the RAPD markers and the respective numbers of polymorphic and monomorphic bands

\begin{tabular}{llll}
\hline Primers & Sequence $\mathbf{5}^{\prime}-\mathbf{3}^{\prime}$ & Number of polymorphic bands & Number of monomorphic bands \\
\hline OPD04 & TCTGGTGAGG & 6 & 0 \\
OPD07 & TTGGCACGGG & 4 & 0 \\
OPD08 & GTGTGCCCCA & 5 & 1 \\
OPD10 & GGTCTACACC & 8 & 0 \\
OPE16 & GGTGACTGTG & 3 & 4 \\
OPF01 & ACGGATCCTG & 6 & 0 \\
OPG05 & CTGAGACGGA & 7 & 0 \\
OPH12 & ACGCGCATGT & 7 & 3 \\
\hline Total & & $\mathbf{4 6}$ & $\mathbf{8}$ \\
\hline
\end{tabular}

The use of molecular markers is highly practical because it allows a fast study of the existing variability, with the attainment of a limitless number of genetic polymorphisms and no influence of the environment, in addition to allowing the detection of polymorphisms at any stage of plant development (Faleiro, 2007). In this study, the genetic variability among genotypes was confirmed by the high percentage of polymorphic markers. High polymorphism was reported by Bellon et al. (2014) when estimating the genetic variability in wild and commercial accessions of $P$. edulis.

Several authors have observed variability in yellow passion fruit. Bellon et al. (2007) recorded an average number of 14.4 bands per primer whereas Cerqueira-Silva et al. (2010) found 5.7 bands per primer. An average number of 6.8 bands per primer was observed in this study. Therefore, these data demonstrate considerable variability among genotypes, which can be exploited in future conservation and breeding researches.

Genetic variability among genotypes was expected to be detected since yellow passion fruit is a self-incompatible allogamous plant, which prevents self-fertilization and the crossing of different plants that contain the same incompatibility alleles (Santos et al., 2011). As a result, gene flow among genotypes is favored during cross-pollination. The high variability observed is also due to the broad genetic base observed in the passion fruit breeding programs of the University of Brasilia and Embrapa Cerrados, which is the result of crosses between accessions of different geographic origins at the base of the crossings (Bellon et al., 2005).

Genetic dissimilarities varied from 0.043 to 0.451 among genotypes. The highest genetic distance was verified between Rosa Intenso 3 and AP01 (Figure 1). As stated by Santos et al. (2011), the success of passion fruit breeding programs is closely related to the appropriate choice of divergent parents, which when crossed must result in wide genetic variability to be used for selection among segregating populations. Therefore, the identification of parents with high genetic variability has been a goal of many breeding programs that aim to explore the heterosis. 


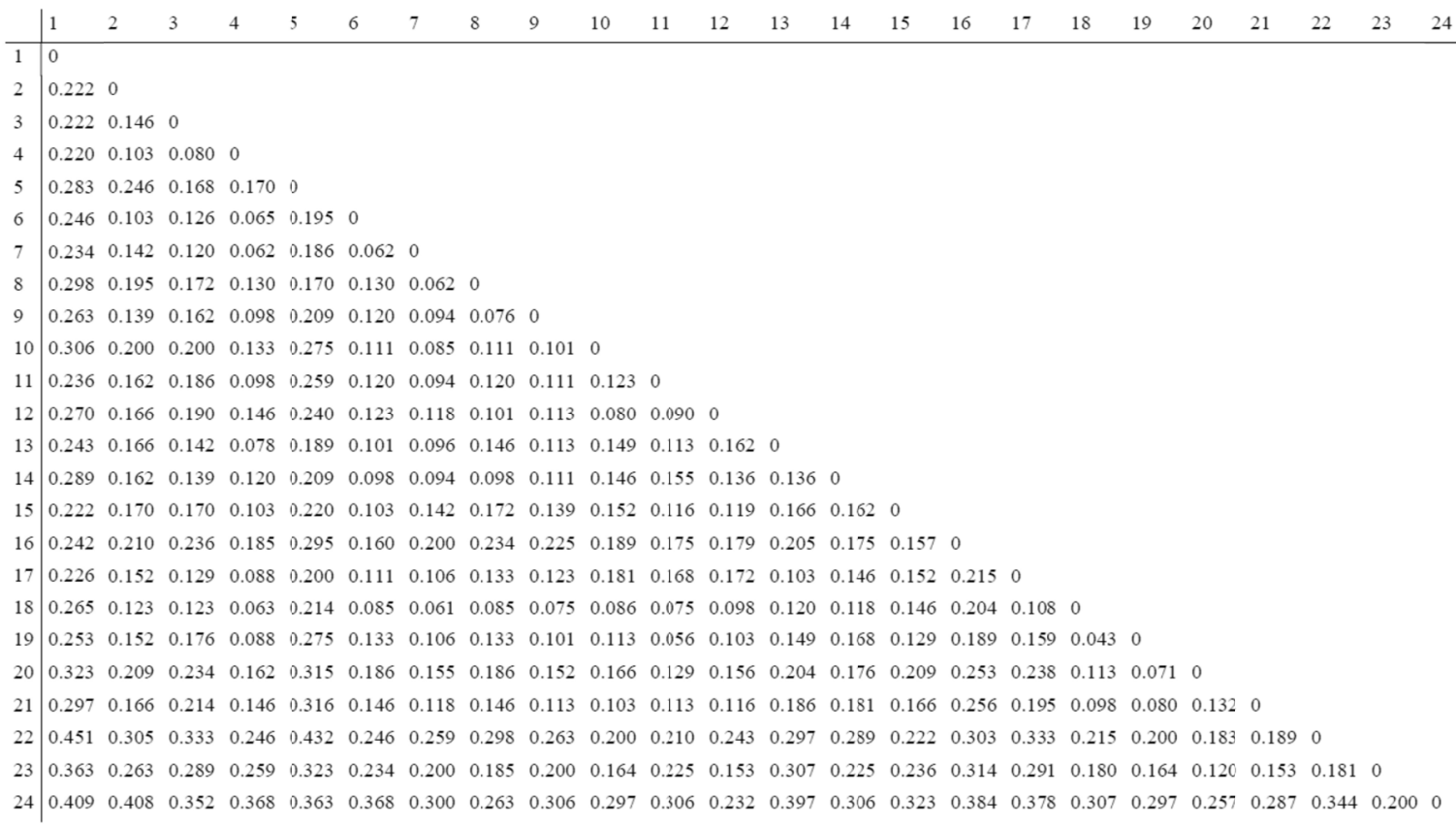

Figure 1. Matrix of genetic distance based on the coefficient of Nei and Li among pairs of yellow passion fruit (Passiflora edulis Sims) genotypes, through RAPD markers. 1) Rosa Intenso 3; 2) MAR20\#44; 3) MAR20\#15; 4) ECL-7; 5) EC3-0; 6) MAR20\#39; 7) MAR20\#2005 PL2; 8) Rosa Intenso PL1; 9) MSCA; 10) MAR20\#19; 11) MAR20\#2005 PL1; 12) MAR20\#41; 13) MAR20\#46; 14) AP01; 15) AR02; 16) MAR20\#34 F2; 17) MAE20\#49; 18) Rosa Claro PL1; 19) MAR20\#12 PL1; 20) Gigante Amarelo PL1; 21) Rosa Claro PL2; 22) MSCA PL1; 23) Rubi Gigante PL2; 24) MAR20\#24 PL1

Genotypes were subdivided into at least six groups of similarity (Figure 2). These genetic distances characterize the existence of significant genetic diversity among genotypes, which was also verified by Vilela (2013), who recorded genetic distances ranging from 0.080 to 0.390 for 32 passion fruit genotypes and seven groups of similarity at a relative genetic distance of 0.190 . In the molecular characterization of passion fruit genotypes with different yield and disease resistance levels, Castro (2015) identified genetic distances ranging from 0.04 to 0.350. The genotypes were subdivided into at least five groups of similarity. As a consequence, the genetic diversity among 24 passion fruit genotypes evaluated in this study can be combined with the performance of these genotypes in field conditions to direct breeding programs towards obtaining high-yielding and disease resistant genotypes. 

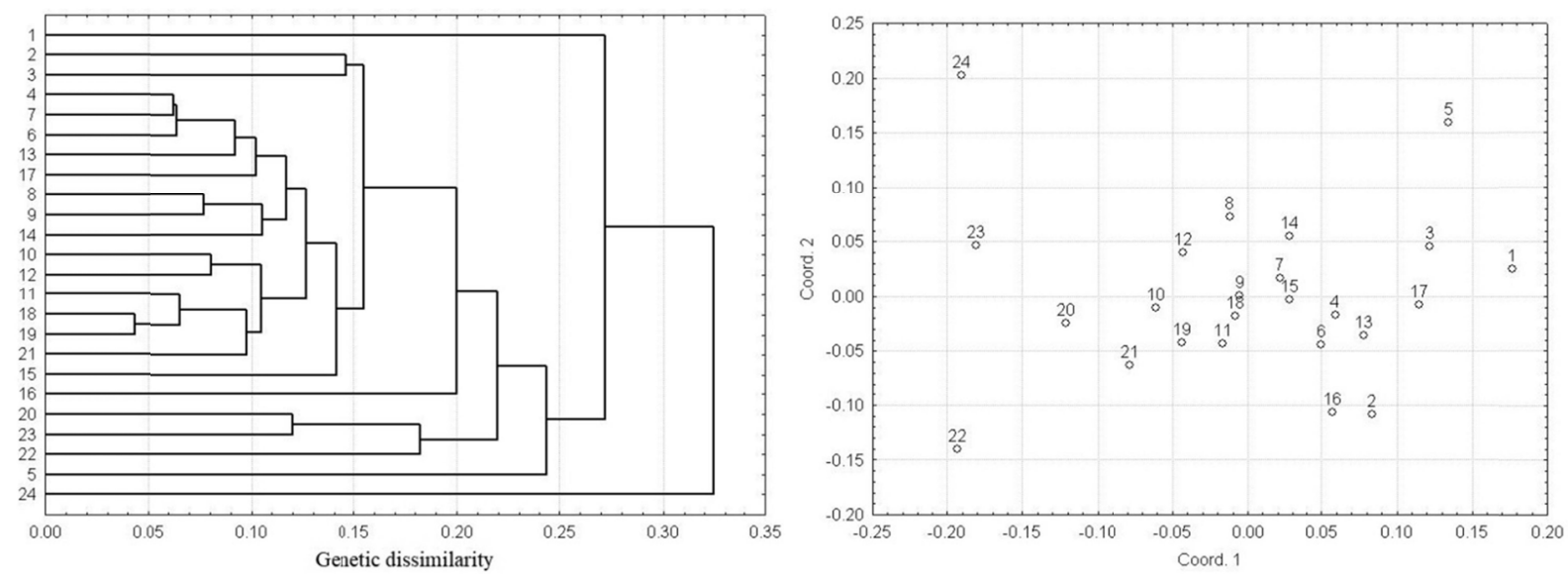

Figure 2. Clustering and dispersion analysis of 24 yellow passion fruit (Passiflora edulis Sims) genotypes using the unweighted pair group method with arithmetic mean (UPGMA) of distances estimated for the Nei and Li coefficient from RAPD bands. 1) Rosa Intenso 3; 2) MAR20\#44; 3) MAR20\#15; 4) ECL-7; 5) EC3-0; 6) MAR20\#39; 7) MAR20\#2005 PL2; 8) Rosa Intenso PL1; 9) MSCA; 10) MAR20\#19; 11) MAR20\#2005 PL1; 12) MAR20\#41; 13) MAR20\#46; 14) AP01; 15) AR02; 16) MAR20\#34 F2; 17) MAE20\#49; 18) Rosa Claro PL1; 19) MAR20\#12 PL1; 20) Gigante Amarelo PL1; 21) Rosa Claro PL2; 22) MSCA PL1; 23) Rubi Gigante PL2; 24) MAR20\#24 PL1

\section{Conclusion}

The high genetic variability among genotypes indicates the broad genetic basis of the species. Genotypes were subdivided into at least five groups of similarity. Our results indicate that RAPD markers can be useful for genetic diversity studies, to provide practical information for parental selection and to assist breeding and conservation strategies.

\section{References}

ABF (Anuário Brasileiro da Fruticutura). (2018). Santa Cruz do Sul, RS: Editora Gazeta Santa Cruz.

Bellon, G, Faleiro, F. G, Junqueira, K. P., \& Junqueira, N. T. V. (2007) Variabilidade genética de acessos silvestres e comerciais de Passiflora edulis Sims. com base em marcadores RAPD. Revista Brasileira de Fruticultura, 29(1), 124-127. https://doi.org/10.1590/S0100-29452007000100027

Bellon, G., Faleiro, F. G., Junqueira, K. P., Paula, M. S., Braga, M. F., Junqueira, N. T. V., \& Peixoto, J. R. (2005). Diversidade genética de acessos comerciais e silvestres de maracujazeiro-doce com base nos marcadores RAPD. In F. G. Faleiro, N. T. V. Junqueira, \& M. F. Braga (Eds.), IV Reunião Técnica de Pesquisas em Maracujazeiro (pp. 118-121). Planaltina, DF: Embrapa Cerrados.

Bellon, G., Faleiro, F. G., Junqueira, N. T. V., \& Fuhrmann, E. (2014). Variabilidade genética de genótipos elite de maracujazeiro, obtidos em programas de retrocruzamento envolvendo espécies silvestres e comerciais com base em marcadores RAPD. Bioscience Jounal, 30(6), 1692-1697.

Bernacci, L. C., Cervi, A. C., Milward-De-Azevedo, M. A., Nunes, T. S., Imig, D. C., \& Mezzonato, A. C. (2015). Passifloraceae. In Lista de Espécies da Flora do Brasil. Retrieved September 5, 2018, from http://floradobrasil.jbrj.gov.br/jabot/floradobrasil/FB182

Castro, A. P. G. (2015). Desempenho agronômico, diversidade genética e avaliação de doenças em progênies de maracujazeiro-azedo (Doctoral dissertation, Universidade de Brasilia, Brasilia, Brazil). Retrieved from http://repositorio.unb.br/handle/10482/19082

Cerqueira-Silva, C. B. M., Conceição, L. D. H. C. S., Cardoso-Silva, C. B., Pereira, A. S., Santos, E. S. L., Oliveira, A. C., \& Correa, R. X. (2010). Genetic diversity of yellow passion fruit (Passiflora edulis Sims) based on RAPD markers. Crop Breeding and Applied Biotechnology, 10(2), 154-159. https://doi.org/ 10.12702/1984-7033.v10n02a08

Cerqueira-Silva, C. B. M., Jesus, O. N., Santos, E. S. L., Corrêa, R. X., \& Souza, A. P. (2014). Genetic Breeding and Diversity of the Genus Passiflora: Progress and Perspectives in Molecular and Genetic Studies. International Journal of Molecular Sciences, 15(8), 14122-14152. https://doi.org/10.3390/ijms150814122 
Cruz, C. D. (2013). Genes: A software package for analysis in experimental statistics and quantitative genetics. Acta Scientiarum: Agronomy, 35(3), 271-276. https://doi.org/10.4025/actasciagron.v35i3.21251

Cunha, M. A. P., \& Barbosa, L. C. (2002). Aspectos botânicos. In A. A. Lima (Ed.), Maracujá produção: Aspectos técnicos (pp. 11-14). Cruz das Almas, BA: Embrapa Mandioca e Fruticultura Tropical.

Faleiro, F. G. (2007). Marcadores moleculares aplicados a programas de conservação e uso de recursos genéticos. Planaltina, DF: Embrapa Cerrados.

Faleiro, F. G., Faleiro, A. S. G., Cordeiro, M. C. R., \& Karia, C. T. (2003). Metodologia para operacionalizar a extração de DNA de espécies nativas do cerrado. Planaltina, DF: Embrapa Cerrados.

Faleiro, F. G., Pires, J. L, Monteiro, W. R., Lopes, U. V., Yamada, M. M., Piedra, A. G., ... Santos, M. C. M. (2004). Variability in cacao accessions from the Brazilian, Ecuadorian, and Peruvian Amazons based on molecular markers. Crop Breeding and Applied Biotechnology, 4, 227-233.

Fonseca, F. G., Faleiro, F. G., Junqueira, N. T., Barth, M., \& Feldberg, N. P. (2017). Morphoagronomic and molecular characterization of ornamental passion fruit cultivars. Pesquisa Agropecuária Brasileira, 52(10), 849-860. https://doi.org/10.1590/S0100-204X2017001000004

Kososki, R. M. (2014). Diversidade genética e reação de genótipos de maracujazeiro a septoriose, verrugose e mancha oleosa em casa de vegetação (Doctoral dissertation, Universidade de Brasilia, Brasilia, Brazil). Retrieved from http://repositorio.unb.br/handle/10482/17282

Meletti, L. M. M., \& Brückner, C. H. (2001). Melhoramento Genético. In C. H. Brückner, \& M. C. Picanço (Eds.), Maracujá: Tecnologia de produção, pós-colheita, agroindústria, mercado (pp. 345-385). Porto Alegre, RS: Cinco Continentes.

Nei, M., \& Li, W. H. (1979). Mathematical model for studying genetic variation in terms of restriction endonucleases. Proceedings of the National Academy of Science, 76(10), 5269-5273. https://doi.org/ 10.1073/pnas.76.10.5269

Neves, C. G., Jesus, O. N., Ledo, C. A. S., \& Oliveira, E. J. (2013). Avaliação agronômica de parentais e híbridos de maracujazeiro-amarelo. Revista Brasileira de Fruticultura, 35(1), 191-198. https://doi.org/10.1590/ S0100-29452013000100022

Pereira, M. G., Pereira, T. N. S., \& Viana, A. P. (2005). Marcadores moleculares aplicados ao melhoramento genético do maracujazeiro. In F. G. Faleiro, N. T. V. Junqueira, \& M. F. Braga (Eds.), Maracujá: Germoplasma e Melhoramento Genético (pp. 275-292). Planaltina, DF: Embrapa Cerrados.

Santos, L. F., Oliveira, E. J., Silva, A. S., Carvalho, F. M., Costa, J. L., \& Pádua, J. G. (2011). ISSR Markers as a tool for the assessment of genetic diversity in Passiflora. Biochemical Genetics, 49, 540-554. https://doi.org/10.1007/s10528-011-9429-5

Statsoft Inc. (2000). Statistics for Windows (Computer Program manual). Tulsa: Statsoft Inc.

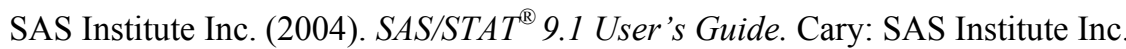

Vilela, M. S. (2013). Diversidade genética, produtividade e reação de progênies de maracujazeiro à doenças sob condições de campo (Doctoral dissertation, Universidade de Brasilia, Brasilia, Brazil). Retrieved from http://repositorio.unb.br/handle/10482/13705

\section{Copyrights}

Copyright for this article is retained by the author(s), with first publication rights granted to the journal.

This is an open-access article distributed under the terms and conditions of the Creative Commons Attribution license (http://creativecommons.org/licenses/by/4.0/). 